CLINICAL STUDY

\title{
Magnetic resonance imaging study of pituitary morphology in subjects homozygous and heterozygous for a null mutation of the GHRH receptor gene
}

\author{
Helio A Oliveira, Roberto Salvatori ${ }^{1}$, Miriam P O Krauss, Carla R P Oliveira, Paula R C Silva and \\ Manuel H Aguiar-Oliveira \\ Endocrinology and Radiology Divisions, Federal University of Sergipe, Aracaju, SE 49060-100, Brazil and ${ }^{1}$ Division of Endocrinology, \\ Johns Hopkins University, 1830 East Monument Street no. 333, Baltimore, Maryland 21287 USA \\ (Correspondence should be addressed to Roberto Salvatori; Email: salvator@jhmi.edu)
}

\begin{abstract}
Objective: Somatotrophs represent the majority of cells in the anterior pituitary, and their numeric reduction can cause anterior pituitary hypoplasia (APH). Small numbers of patients with familial isolated GH deficiency (IGHD) due to bi-allelic mutations in the GHRH receptor (GHRHR) gene (GHRHR) have been reported to have APH. We tested if APH was present in a large cohort of patients homozygous and heterozygous for a GHRHR mutation.

Design: We studied pituitary morphology in adult and pediatric age subjects ( 8 years of age and older) belonging to a large extended Brazilian kindred with a high prevalence of IGHD due to a null GHRHR mutation.

Methods: We performed brain magnetic resonance imaging (MRI) in 38 subjects, divided into four groups: group I: normal adults (five males, four females, age $38 \pm 11.7$ years); group II: heterozygous adults (six males, seven females, age $42.23 \pm 8.8$ years); group III: homozygous GH-naive affected adults (three males, five females, age $41.4 \pm 15.0$ years); group IV: homozygous affected children (three males, five females, age $11.9 \pm 2.5$ years). Results are expressed as means \pm s.D.

Results: Pituitary height (mm) was not different between groups II and I (4.61 \pm 1.55 and $4.41 \pm 0.62$ respectively), but it was significantly reduced in groups III $(2.67 \pm 0.87, P<0.001)$ and IV $(2.87 \pm 0.79, P<0.001)$ compared with group I. Pituitary volume $\left(\mathrm{mm}^{3}\right)$ was normal in group II (417.12 \pm 140.86$)$, but it was significantly reduced in groups III and IV (124.06 564.27 and $155.68 \pm 39.79$ respectively vs $414.56 \pm 71.57$; both $P<0.001$ ). The volume ratio (calculated by multiplying the pituitary volume by 1000 and dividing it by cranial volume) was significantly lower in the affected subjects (groups III and IV) $(0.06 \pm 0.02)$ than in unaffected (groups I and II) $(0.15 \pm 0.04 ; P<0.0001)$, demonstrating that $\mathrm{APH}$ is not due to reduction of cranial volume.

Conclusions: APH is present from childhood in patients homozygous for an inactivating GHRHR mutation, but it does not occur in heterozygous subjects. In our cohort, the presence of normal anterior pituitary size by MRI rules out homozygosity for a GHRHR mutation in subjects who are 8 years of age or older.
\end{abstract}

European Journal of Endocrinology 148 427-432

\section{Introduction}

Isolated growth hormone deficiency (IGHD) can be caused by acquired or genetic abnormalities of the hypothalamus or the pituitary. Initial magnetic resonance imaging (MRI) studies of the hypothalamic and pituitary area had reported that the majority of IGHD patients $(88 \%)$ had normal pituitary size, but the cutoff considered normal for pituitary height in this study was only $2 \mathrm{~mm}$, without any adjustment for age (1). It was later reported that pituitary size changes during childhood $(2,3)$. Using age-adjusted measurements, it was discovered that the majority of IGHD patients had anterior pituitary hypoplasia (APH) (4), often associated with the pituitary stalk agenesis (PSA) syndrome, which includes pituitary stalk transection and ectopic neurohypophysis (5-7). Although more often associated with PSA, APH may be an isolated finding in IGHD (8-11). In addition, while patients with APH associated with PSA have a high risk of developing multiple pituitary hormone deficiencies, patients with isolated APH often have a phenotype limited to IGHD, and may even normalize their GH secretion and pituitary size after reaching adulthood (10).

As somatotroph cells represent $50-60 \%$ of the pituitary gland mass (12), their absence or reduced 
number may be responsible for APH. Because growth hormone-releasing hormone (GHRH) has an important role in regulating the proliferation and functional activity of somatotroph cells (13), abnormalities causing alteration of the GHRH pathway may cause APH. Accordingly, a naturally occurring animal model of IGHD due to a GHRH receptor (GHRHR) mutation (little mouse) exhibits APH due to somatotroph cell hypoplasia (14).

The most frequent causes of inherited IGHD are mutations in the gene encoding for GH (GH1) (15) or in the gene encoding for the GHRHR (GHRHR) (16-25). Familial IGHD has been classified in four forms, according to degree of GH deficiency and mode of inheritance. Type IA has autosomal recessive inheritance, patients have complete lack of serum GH and frequently develop anti-GH antibody after therapy with exogenous $\mathrm{GH}$; it is due to large homozygous deletions in the GH1 gene. Type IB is autosomal recessive, patients have low but measurable serum GH levels, and show a good response to exogenous GH therapy; it may be due to homozygous GH1 or GHRHR mutations. Type II is autosomal dominant, with low but measurable serum GH levels, and a good response to exogenous GH therapy; it is often caused by heterozygous GH1 mutations that, with different molecular mechanisms, cause deletion of exon 3. The most rare form is type III, transmitted as an $\mathrm{X}$-linked character, whose genetic cause is not fully elucidated (26).

Although no pathological studies have been done in humans, patients with IGHD IB caused by bi-allelic mutations in the GHRHR gene have been reported to have radiological evidence of APH without other abnormalities of the pituitary or stalk. MRI studies of these patients have been done in a limited number of cases $(18,20,22-25,27)$, and have never included heterozygous carriers. As heterozygous carriers of GHRHR mutations have been reported to have lower serum insulin-like growth factor-I (IGF-I) than normal subjects $(17,28)$, it is conceivable that they may have a pituitary size that may be intermediate between normal and affected subjects.

In this study, we have examined brain morphology by MRI in subjects from an extended kindred residing in Itabaianinha, Brazil with high prevalence of familial IGHD IB due to a null mutation in the GHRHR gene that causes severe IGHD in the homozygous state (19, $28,29)$. The goal of this study was to assess pituitary morphology in homozygous adult and pediatric IGHD patients and in heterozygous adult subjects.

\section{Subjects and methods}

Thirty-eight individuals from Itabaianinha, Brazil underwent MRI imaging of the hypothalamic-pituitary area. The affected individuals were selected based on
IGHD phenotype, while the normal and heterozygous subjects were selected randomly among family members of affected individuals. The clinical and hormonal findings in the homozygous affected have been described previously $(19,28-30)$. All subjects were genotyped for the IVS1+1 $\mathrm{G} \rightarrow \mathrm{A}$ mutation of the GHRHR gene via denaturing gradient gel electrophoresis of amplified genomic DNA obtained from buccal smears (19). They were divided into four groups according to genotyping results and age: group I: homozygous normal adults (five males and four females; $38 \pm 11.7$ years); group II: heterozygous adults (six males and seven females; 42.23 \pm 8.8 years); group III: homozygous GH-naive affected adults (three males and five females; 41.4 \pm 15.0 years); group IV: homozygous affected children (three males, 8-13 years and five females, 9-14 years; $11.9 \pm 2.5$ years) who had been on GH treatment for about 3 years. All the affected individuals had a typical IGHD phenotype (very short stature, central obesity and a high-pitched voice), very low serum IGF-I levels, and no serum GH response to clonidine and hypoglycemic test. Cephalic perimeter $(\mathrm{CP}, \mathrm{cm})$ was compared with previously published data (31) to calculate $\mathrm{CP}$ standard deviation score (SDS). Approximate cephalic volume $\left(\mathrm{CV}, \mathrm{cm}^{3}\right)$ was calculated assuming a spherical shape using the formula $\mathrm{CV}=4 / 3 \pi r^{3}$.

In group IV, stature and $\mathrm{CP}$ had increased by $22 \pm 10 \mathrm{~cm}$ and $2.6 \pm 1.38 \mathrm{~cm}$ respectively while on $\mathrm{GH}$ treatment. The wide range of the stature increments reflects periodic interruptions of $\mathrm{GH}$ treatment due to intermittent drug availability.

MRI was performed with a General Electric apparatus, model Signa Horizon LX - 1,0 T-system (Waukeska, WI, USA). Contiguous sagittal and coronal spin-echo $T_{1}$-weighted sequences $\left(416 / 16\left(T_{\mathrm{R}} / T_{\mathrm{E}}\right), 2 \mathrm{~mm}\right.$ thick $)$ and Fast Spin Echo (FSE) $T_{2}$-weighted sequences $\left(4.300 / 102\left(T_{\mathrm{R}} / T_{\mathrm{E}}\right), 2 \mathrm{~mm}\right.$ thick) were obtained without contrast administration. We did not administer contrast because its absence does not impair measurements of the pituitary (32). Maximal anterior pituitary height ( $\mathrm{mm})$ was determined from midline sagittal images by measuring the greatest distance between the superior and inferior borders of the gland. Width $(\mathrm{mm})$ and length (mm) were similarly measured by the greatest dimensions on the coronal and sagittal images respectively. Estimates of pituitary volume $\left(\mathrm{PV}, \mathrm{mm}^{3}\right)$ were derived from these measures using the average of the cubic (length $\times$ width $\times$ height) and the ellipsoid [(length $\times$ width $\times$ height)/2] formulas (33). Pituitary measurements were compared with previously published values adjusted for sex and age (2, 3), and SDSs were calculated.

To determine the relationship between PV and CV in each group, a volume ratio (VR) was calculated by multiplying PV by 1000 and dividing it by CV. To determine the ratio between individual values and the mean of the normal group, two others values were calculated in the adults: the ratio of pituitary volume 
(RPV) and the ratio of cranial volume (RCV), obtained by dividing the individual values of groups II and III by the average of group I. MRI images were also examined for morphology of the pituitary stalk and neurohypophysis, and for other cranial abnormalities.

The appropriate institutional review committees approved this study and all the subjects or their parental guardians gave informed consent.

Data were analyzed by the non-parametric MannWhitney and Spearman tests using the program SPSS 8.0 (Statistical Package for Social Science). Data are expressed as means \pm S.D. and $P$ values $<0.05$ were considered to be significant.

\section{Results}

Anthropometric data and serum IGF-I levels of the subjects included in the study are shown in Table 1. Stature was significantly lower in group III than in group I $(P<0.001)$. Serum IGF-I levels were lower in groups II, III and IV than in group I, although the difference was much more marked for groups III and IV. In group III, both $\mathrm{CP}$ and $\mathrm{CV}$ were significantly lower than in group I $(P<0.001)$. No difference was observed between group II and I. Homozygous affected children exhibited larger $\mathrm{CP}$ and $\mathrm{CV}$ values (although not statistically significant) than $\mathrm{GH}-$ naive adults, possibly due to the effect of $\mathrm{GH}$ treatment in early years of life. As we did not have normal controls for children, we could not compare directly the $\mathrm{CP}$ and $\mathrm{CV}$ of affected children with age-matched controls.
Table 2 shows the data on pituitary morphology. There was no difference between groups II and I in any of the parameters. Groups III and IV exhibited reduced values for all the measurements (pituitary height, height SDS, length, width, volume and VR) in comparison with group I. Pituitary height was $2.50 \pm 1.11 \mathrm{~mm}$ in three children between 5 and 10 years of age, and $3.10 \pm 1.18$ in those between 10 and 15 years of age. Pituitary height SDS is more markedly reduced in group IV than in group III (see below), despite similar absolute values. There was no statistical difference in any of the measurements (pituitary height, length, width and volume) between groups III and IV.

There was a correlation between PV and stature and between PV and serum IGF-I when we examined all 38 subjects. Both correlations were abolished, however, when we examined the two affected groups, either individually or pooled together, indicating that within the groups PV does not predict GH secretion. The SDSs of pituitary height in groups III and IV were severely reduced $(-1.95 \pm 0.58$ and $-2.84 \pm 0.64, P<0.01$ and $P<0.001$ compared to group I, respectively), demonstrating the marked APH in the homozygous affected adults and children. The PV of the heterozygous group was normal. The VR was reduced in the pooled affected subjects (groups III and IV) $(0.06 \pm 0.02)$ compared with pooled groups I and II (0.15 $\pm 0.04 ; P<0.0001)$, showing that the decrease in $\mathrm{PV}$ observed in affected subjects is not due to the decrease in the whole CV. This finding is confirmed by the fact that in affected adults RPV and RCV were reduced by $71 \%$ and $22 \%$ respectively in group III in

Table 1 Anthropometric data and IGF-I levels (mean \pm S.D.) in normal homozygous (group I), and in subjects heterozygous (group II) or homozygous (group III, adults; group IV, children) for the IVS1+1 G $\rightarrow$ A GHRHR mutation.

\begin{tabular}{lcccc}
\hline & Group I $(n=9)$ & Group II $(n=13)$ & Group III $(n=8)$ & Group IV $(n=8)$ \\
\hline Sex (M/F) & $5 / 4$ & $6 / 7$ & $3 / 5$ & $3 / 5$ \\
Age (years) & $38.00 \pm 11.7$ & $42.23 \pm 8.8$ & $41.37 \pm 15.04$ & $11.87 \pm 2.47$ \\
Stature (cm) & $154 \pm 12$ & $153 \pm 10$ & $117 \pm 5^{\mathrm{b}}$ & $96 \pm 11$ \\
IGF-I (nmol/l) & $25.68 \pm 7.24$ & $19.10 \pm 6.81^{\mathrm{a}}$ & $0.19 \pm 0.06^{\mathrm{b}}$ & $0.69 \pm 0.66^{\mathrm{b}}$ \\
CP $(\mathrm{cm})$ & $54.66 \pm 1.22$ & $54.57 \pm 1.63$ & $50.42 \pm 1.14^{\mathrm{b}}$ & $51.68 \pm 1.38$ \\
CV $\left(\mathrm{cm}^{3}\right)$ & $2765.26 \pm 184.91$ & $2754.19 \pm 253.19$ & $2169.73 \pm 147.69^{\mathrm{b}}$ & $2338.64 \pm 186.30$ \\
\hline
\end{tabular}

${ }^{\mathrm{a}} P<0.05$ in comparison with group I; ${ }^{\mathrm{b}} P<0.001$ in comparison with group I.

Table 2 Pituitary morphologic data (mean \pm s.D.) in normal homozygous (group I), and in subjects heterozygous (group II) or homozygous (group III, adults; group IV, children) for the IVS1+1 G $\rightarrow$ A GHRHR mutation. VR was calculated by multiplying PV by 1000 and dividing it by CV.

\begin{tabular}{lccrr}
\hline & Group I & Group II & Group III & Group IV \\
\hline Pituitary height (mm) & $4.41 \pm 0.62$ & $4.61 \pm 1.55$ & $2.67 \pm 0.87^{\mathrm{b}}$ & $2.87 \pm 0.79^{\mathrm{b}}$ \\
Pituitary height SDS & $-0.90 \pm 0.08$ & $-0.39 \pm 1.1$ & $-1.95 \pm 0.58^{\mathrm{a}}$ & $-2.84 \pm 0.64^{\mathrm{b}}$ \\
Pituitary length (mm) & $9.55 \pm 0.88$ & $10.38 \pm 1.85$ & $7.00 \pm 1.85^{\mathrm{b}}$ & $7.56 \pm 1.23^{\mathrm{b}}$ \\
Pituitary width (mm) & $13.44 \pm 1.58$ & $12.38 \pm 2.81$ & $8.50 \pm 2.00^{\mathrm{b}}$ & $10.00 \pm 1.10^{\mathrm{b}}$ \\
Pituitary volume (mm $\left.{ }^{3}\right)$ & $414.56 \pm 71.57$ & $417.12 \pm 140.86$ & $124.06 \pm 64.27^{\mathrm{b}}$ & $155.68 \pm 39.79^{\mathrm{b}}$ \\
VR & $0.15 \pm 0.03$ & $0.15 \pm 0.05$ & $0.05 \pm 0.02^{\mathrm{b}}$ & $0.06 \pm 0.01^{\mathrm{b}}$ \\
\hline
\end{tabular}

${ }^{\mathrm{a}} P<0.01$ in comparison with group I; ${ }^{\mathrm{b}} P<0.001$ in comparison with group $\mathrm{I}$. 
comparison with group I $(P<0.001)$. There were no differences in these variables between groups II and I.

The pituitary stalk and neurohypophysis appeared normal in all the subjects, and none of the other abnormalities often reported in association with sporadic $\mathrm{GH}$ deficiency were detected.

\section{Discussion}

In this report we describe MRI data on pituitary morphology in 38 individuals from the Itabaianinha kindred, characterized by high prevalence of the IVS1+1 G $\rightarrow$ A GHRHR mutation. The exceptionally large size of this kindred has allowed us to generate statistically significant data not obtainable in smaller kindreds. However, the uniform genetic background of the individuals studied may in part limit the applicability of our results to patients with a different genetic background.

We have observed marked APH in all the adults and children homozygous for a null GHRHR mutation when compared with normal adults and with published data on children and adults (2, 34-36). APH was also present in affected pubertal children in whom pituitary height is normally increased. Although CV is reduced, the more marked reduction of the PV shows that the decrease in PV is not due to the decrease in the whole $\mathrm{CV}$, but reflects selective reduction in pituitary size.

The SDS deficit of pituitary height was more marked in affected children $(-2.84 \pm 0.64)$ than in affected adults $(-1.95 \pm 0.58)$, despite very similar absolute height values (the difference in PV between adult and pediatric age affected children is not statistically significant). This is due to the fact that in normal subjects the pituitary height peaks in late childhood (age 10-19) (2), possibly due to somatotroph cell hyperplasia. This enlargement does not seem to occur (or is less marked) in our homozygous affected children, causing more marked reduction in SDS. We speculate that this lack of increase in pituitary size may be due to lack of GHRH effect on the somatotrophs. Our patients therefore differ from the six IGHD patients with small pituitary glands reported by Maghnie et al. (10), who normalized their PV and GH secretion after reaching adulthood. Those patients had a moderate degree of GH deficiency, as demonstrated by height SDS at the time of diagnosis of GH deficiency (at age 7.2-14 years) ranging from -2.7 to -0.1 . It is very unlikely that any of them had a bi-allelic GHRHR mutation, as by age 7 lack of functional GHRHR causes more severe growth failure $(17-25)$.

The degree of APH we detected is comparable with the two previously published smaller reports of a total of six IGHD patients with a homozygous nonsense GHRHR mutation (Glu72X) $(18,27)$. One difference is that we found a reduction in all three dimensions (height, length and width) while Murray et al. (27) found a reduction only in the first two. The reason for this difference is not clear, as both mutations (IVS1+1 G $\rightarrow$ A and Glu72X) are predicted to cause complete lack of functional GHRHR. Although our adults were older than the subjects studied by Murray et al. (22-29 years of age), we doubt that this difference is significant, as we did not observe any change in pituitary size with age in the homozygous patients.

Recently, Osorio et al. (37), within a large series of 76 Brazilian patients with IGHD or combined pituitary hormone deficiency (CPHD), described four patients with bi-allelic mutations in the GHRHR gene. Two of them (one homozygous for the same IVS $1+1 \mathrm{G} \rightarrow \mathrm{A}$ mutation of the Itabaianinha kindred and one with compound heterozygosity for two separate mutations) had severe APH. The other two (ages 10 and 12 years) (both homozygous for the IVS1+1 $\mathrm{G} \rightarrow \mathrm{A}$ mutation) had almost normal pituitary height $(-0.3$ and -1.7 SDS, according to our age- and sex-adjusted calculation). Regrettably, PV was not reported. We cannot explain this discrepancy, as we found evident hypoplasia in all the 16 subjects we studied who were homozygous for this mutation.

In affected adult individuals we did not find any correlation between PV and serum IGF-I, or the previously reported (27) correlation between PV and stature. However, Murray et al. (27) analyzed four affected adults, while this study included twice as many, and the significance of the correlation they found was borderline $(P \sim 0.03)$. An attempt to correlate PV with stature in children would not be reliable, as they have been treated with $\mathrm{GH}$ at various ages.

Bozzola et al. (5) found MRI evidence of isolated APH in $75 \%$ of 60 IGHD patients, and Arrigo et al. (38) reported IGHD in $78.1 \%$ of patients with APH without PSA, demonstrating that IGHD and APH are frequently associated. We found none of the abnormalities in pituitary stalk and neurohypophysis reported in other IGHD etiologies $(6,39)$. APH may be caused by a variety of insults to the hypothalamic area, including infections, ischemia, inflammation or trauma, which may result in IGHD or CPHD, and is therefore by no means diagnostic of GHRHR mutations. Patients with mutations in the GH1 have been reported to have normal or only mildly decreased pituitary size (40-42). However, $\mathrm{APH}$ is not a unique feature of mutations in the GHRHR gene. APH in the setting of genetic IGHD IB can also be caused by heterozygous mutations in the homeobox gene HESX1 (43). In addition, as some patients with CPHD caused by mutations in the genes encoding for the pituitary-specific transcription factors POU1F1 and PROP1 may initially present with IGHD and $\mathrm{APH}$, and manifest lack of other hormones at older ages (44), clinicians should consider this possibility, particularly in younger children.

One important question relates to the time of onset of APH. The youngest patient we studied was 8 years old, and he already had evident APH. We could not study 
younger children, as it would have required sedation, with its associated risks. Therefore, we cannot determine whether APH is present at birth or appears in the postnatal period, as in the little mouse (14).

This study is the first to examine MRI findings in subjects heterozygous for a GHRHR mutation. Other reports have suggested a reduction of stature and lower serum IGF-I levels in heterozygous in comparison with homozygous normal individuals $(17,28)$. Our finding of lower IGF-I levels in the heterozygous group may indeed confirm a reduction in $\mathrm{GH}$ secretion. However, there was no difference in pituitary morphology between heterozygous and normal subjects to support the concept that such a reduction reflects a reduced somatotroph cell mass.

We conclude that, in patients homozygous for an inactivating mutation of the GHRHR gene, APH is evident by MRI from childhood. APH does not occur in heterozygous subjects.

APH in the setting of familial IGHD can be caused by defects in several known genes (37), and possibly of other yet undiscovered factors. Therefore, its presence is not diagnostic of mutations in any specific gene. However pituitary MRI, when performed, has shown APH in a total of 32 out of 34 subjects older than 8 years of age bearing a bi-allelic GHRHR mutation (including the 16 reported in this work), independent of the kind of mutation, the genetic background, and the kind of MRI apparatus used $(18,20,22-25,27,37)$. Therefore, APH is a consistent feature of this genetic syndrome. A normal pituitary size by MRI, therefore, makes a mutation in the GHRHR gene in children with familial IGHD IB who are 8 years of age or older very unlikely, but does not help in determining which other gene might be causing the disease.

\section{Acknowledgements}

We wish to thank the subjects who volunteered their time for the studies. This work was supported in part by NIH-NCRR GCRC-CAP award 3 MO1 RR000052$38 \mathrm{~S} 1$ (RS), and by a grant from the Genentech Center for Clinical Research and Education (RS).

\section{References}

1 Cacciari E, Zucchini S, Carla G, Pirazzoli P, Cicognani A, Mandini $\mathrm{M}$ et al. Endocrine function and morphological findings in patients with disorders of the hypothalamo-pituitary area: a study with magnetic resonance. Archives of Diseases in Childhood $1990651199-1202$.

2 Suzuki M, Takashima T, Kadoya M, Konishi H, Kameyama T, Yoshikawa J et al. Height of normal pituitary gland on MR imaging: age and sex differentiation. Journal of Computer Assisted Tomography 199014 36-39.

3 Argyropoulou M, Perignon F, Brunelle F, Brauner R \& Rappaport R. Height of normal pituitary gland as a function of age evaluated by magnetic resonance imaging in children. Pediatric Radiology 199121 247-249.
4 Argyropoulou M, Perignon F, Brauner R \& Brunelle F. Magnetic resonance imaging in the diagnosis of growth hormone deficiency. Journal of Pediatrics 1992120 886-891.

5 Bozzola M, Adamsbaum C, Biscaldi I, Zecca M, Cisternino M, Genovese E et al. Role of magnetic resonance imaging in the diagnosis and prognosis of growth hormone deficiency. Clinical Endocrinology $1996 \mathbf{4 5} 21-26$.

6 Maghnie M, Genovese E, Villa A, Spagnolo L, Campan R \& Severi F. Dynamic MRI in the congenital agenesis of the neural pituitary stalk syndrome: the role of the vascular pituitary stalk in predicting residual anterior pituitary function. Clinical Endocrinology $199645281-290$.

7 Kornreich L, Horev G, Lazar L, Josefsberg Z \& Pertzelan A. MR findings in hereditary isolated growth hormone deficiency. American Journal of Neuroradiology 199718 1743-1747.

8 Nagel BHP, Palmbach D, Petersen D \& Ranke MB. Magnetic resonance images of 91 children with different causes of short stature: pituitary size reflects growth hormone secretion. European Journal of Pediatrics $1997 \mathbf{1 5 6} 758-763$.

9 Hamilton J, Blaser S \& Daneman D. MR imaging in idiopathic growth hormone deficiency. American Journal of Neuroradiology $1998191609-1615$.

10 Maghnie M, Strigazzi C, Tinelli C, Autelli M, Cisternino M, Loche S et al. Growth hormone (GH) deficiency (GHD) of childhood onset: reassessment of $\mathrm{GH}$ status and evaluation of predictive criteria for permanent GHD in young adults. Journal of Clinical Endocrinology and Metabolism $1999 \mathbf{8 4} 1324-1328$.

11 Bozzola M, Mengarda F, Sartirana P, Tato L \& Chaussain JL. Long-term follow-up evaluation of magnetic resonance imaging in the prognosis of permanent GH deficiency. European Journal of Endocrinology $2000143493-496$.

12 Asa SL, Kovacs K \& Melmed S. The hypothalamic-pituitary axis. In The Pituitary, pp 3-44. Ed. S Melmed. Cambridge, MA: Blackwell Science, 1995.

13 Treier M, Gleiberman AS, O'Connell SM, Zeto DP, McMahon JA, McMahon AP et al. Multistep signaling requirements for pituitary organogenesis in vivo. Genes and Development 199812 $1691-1704$.

14 Lin SC, Lin CR, Gukovsky I, Lusis AJ, Sawchenko PE \& Rosenfeld MG. Molecular basis of the little mouse phenotype and implications for cell type-specific growth. Nature $1993 \mathbf{3 6 4}$ 208-213.

15 Philips JA III, Hjelle BL, Seeburg PH \& Zachmann M. Molecular basis for familial isolated growth hormone deficiency. PNAS $1981786372-6375$.

16 Wajnrajch MP, Gertner JM, Harbison MD, Chualer SC \& Leibel RL. Nonsense mutation in the human growth hormone-releasing hormone receptor causes growth failure analogous to the little (lit) mouse. Nature Genetics 199612 88-90.

17 Maheshwari HG, Silverman BL, Dupuis J \& Baumann G. Phenotype and genetic analysis of a syndrome caused by an inactivating mutation in the growth hormone-releasing hormone receptor: dwarfism of Sindh. Journal of Clinical Endocrinology and Metabolism $1998 \mathbf{8 3} 4065-4074$.

18 Netchine I, Talon P, Dastot F, Vitaux F, Goosens M \& Amselem S. Extensive phenotypic analysis of a family with growth hormone (GH) deficiency caused by a mutation in the GH-releasing hormone receptor gene. Journal of Clinical Endocrinology and Metabolism $1998 \mathbf{8 3} 432-436$.

19 Salvatori R, Hayshida CY, Aguiar-Oliveira MH, Phillips JA III, Souza AH, Gondo RG et al. Familial dwarfism due to a novel mutation of the growth hormone-releasing hormone receptor gene. Journal of Clinical Endocrinology and Metabolism $199984917-923$.

20 Salvatori R, Fan X, Phillips JA III, Espigares-Martin R, Martin De Lara I, Freeman KL et al. Three new mutations in the gene for the growth hormone $(\mathrm{GH})$-releasing hormone receptor in familial isolated GH deficiency type IB. Journal of Clinical Endocrinology and Metabolism 200186 273-279.

21 Salvatori R, Fan X, Phillips JA III, Prince M \& Levine MA. Isolated growth hormone $(\mathrm{GH})$ deficiency due to compound heterozygosity 
for 2 new mutations in the GH-releasing hormone receptor gene. Clinical Endocrinology $2001 \mathbf{5 4} 681-688$.

22 Salvatori R, Fan X, Mullis PE, Haile A \& Levine MA. Decreased expression of the growth hormone-releasing hormone receptor gene due to a mutation in a Pit-1 binding site. Molecular Endocrinology $2002 \mathbf{1 6} 450-458$.

23 Salvatori R, Aguiar-Oliveira MH, Monte LBV, Hedges L, Santos NL, Pereira RMC et al. Detection of a recurring mutation in the human growth hormone releasing hormone receptor gene. Clinical Endocrinology 200257 77-80.

24 Salvatori R, Fan X, Veldhuis J \& Couch R. Serum GH response to pharmacological stimuli and physical exercise in two siblings with two new inactivating mutations in the GH-releasing hormone receptor gene. European Journal of Endocrinology $2002 \mathbf{1 4 7}$ 591-596.

25 Carakushansky M, Whatmore AJ, Clayton PE, Shalet SN, Gleeson HK, Price DA et al. A new missense mutation in the growth hormone-releasing hormone receptor gene in familial isolated $\mathrm{GH}$ deficiency. European Journal of Endocrinology 2003148 25-30.

26 Cogan JD \& Phillips JA III. Growth disorders caused by genetic defects in the growth hormone pathway GH deficiency. In Advances in Pediatrics, pp 337-361. Eds LA Barness, G Morron III, AM Rudolph, DC De Vivo, MM Kaback \& WW Tunnessen Jr. St Louis, MO: Mosby, 1998.

27 Murray RA, Maheshwari HG, Russel EJ \& Baumann G. Pituitary hypoplasia in patients with a mutation in the growth hormonereleasing hormone receptor gene. American Journal of Neuroradiology $200021685-689$.

28 Hayashida CY, Gondo RG, Ferrari C, Toledo SP, Salvatori R, Levine MA et al. Familial growth hormone deficiency with mutated GHRH receptor gene: clinical and hormonal findings in homozygous and heterozygous individuals from Itabaianinha. European Journal of Endocrinology 2000142 557-563.

29 Aguiar-Oliveira MH, Gill MS, Barreto ESA, Alcantara MR, Miraki-Moud F, Menezes CA et al. Effect of growth hormone (GH) deficiency due to a mutation in the GH-releasing hormone receptor on insulin-like growth factors (IGFs), IGF-binding proteins, and ternary complex formation throughout. Journal of Clinical Endocrinology and Metabolism $1999 \mathbf{8 4} 4118-4126$.

30 Barreto-Filho JA, Alcântara MRS, Salvatori R, Azevedo M, Barreto $\mathrm{M}$, Sousa AC et al. Familial isolated growth hormone deficiency is associated with increased systolic blood pressure, dyslipidemia and central obesity. Journal of Clinical Endocrinology and Metabolism 200287 2018-2023.

31 Nellhaus G. Head circumference from birth to eighteen years. Practical composite international and interracial graphs. Pediatrics 196841 106-114.

32 Maghnie M, Triulzi F, Larizza D, Scotti G, Beluffi G, Cecchini A et al. Hypothalamic-pituitary dwarfism: comparison between MR imaging and CT findings. Pediatric Radiology 199020 229-235.

33 Di Chiro G \& Nelson KB. The volume of the sella turcica. American Journal of Roentgenology $1962 \mathbf{8 7} 989-1008$
34 Lurie SN, Doraiswamy PM, Husain MM, Boyko OB, Ellinwood EH, Figiel GS et al. In vivo assessment of pituitary gland volume with a magnetic resonance imaging: the effect of age. Journal of Clinical Endocrinology and Metabolism 199071 505-508.

35 Doraiswamy PM, Potts JM, Axelson DA, Husain MM, Lurie SN, $\mathrm{Na} \mathrm{C}$ et al. MR assessment of pituitary gland morphology in healthy volunteers: age and gender related differences. American Journal of Neuroradiology 199213 1295-1299.

36 Tsunoda A, Okuda O \& Sato K. MR height of the pituitary gland as a function of age and sex: especially physiological hypertrophy in adolescence and in climaterium. American Journal of Neuroradiology $1997 \mathbf{1 8} 551-554$.

37 Osorio MG, Marui S, Jorge AA, Latronico AC, Lo LS, Leite CC et al. Pituitary magnetic resonance imaging and function in patients with growth hormone deficiency with and without mutations in GHRH-R, GH-1, or PROP-1 genes. Journal of Clinical Endocrinology and Metabolism 200287 5076-5084.

38 Arrigo T, De Luca F, Maghnie M, Blandino A, Lombardo F, Messina MF et al. Relationships between neuroradiological and clinical features in apparently idiopathic hypopituitarism. European Journal of Endocrinology 1998139 84-88.

39 Marwaha R, Menon PSN, Jena A, Pant C. Sethi AK \& Sapra ML. Hypothalamo-pituitary axis by magnetic resonance imaging in isolated growth hormone deficiency patients born by normal delivery. Journal of Clinical Endocrinology and Metabolism 1992 $74654-659$

40 Zucchini S, Ambrosetto P, Baroncini C \& Cacciari E. Normal pituitary size in two patients with growth hormone gene deletion. Journal of Pediatric Endocrinology and Metabolism $1996 \mathbf{9}$ 545-548.

41 Binder G, Keller E, Mix M, Massa GG, Stokvis-Brantsma WH, Wit JM et al. Isolated GH deficiency with dominant inheritance: new mutations, new insights. Journal of Clinical Endocrinology and Metabolism $1998 \mathbf{8 6} 3877-3881$.

42 Binder G, Nagel BH, Ranke MB \& Mullis PE. Isolated GH deficiency (IGHD) type II: imaging of the pituitary gland by magnetic resonance reveals characteristic differences in comparison with severe IGHD of unknown origin. European Journal of Endocrinology 2002 $147755-760$

43 Thomas PQ, Dattani MT, Brickman JM, McNay D, Warne G, Zacharin M et al. Heterozygous HESX1 mutations associated with isolated congenital pituitary hypoplasia and septo-optic dysplasia. Human Molecular Genetics 2001 $1039-45$.

44 Parks JS, Brown MR, Hurley DL, Phelps CJ \& Wajnrajch MP. Heritable disorders of pituitary development. Journal of Clinical Endocrinology and Metabolism 199984 4362-4370.

Received 30 October 2002

Accepted 8 January 2003 